\title{
Roofing slate from Bernardos, Spain: a potential candidate for global heritage stone
}

\begin{abstract}
Geology Department, Oviedo University, C/ Jesús Arias de Velasco s/n, 33005 Oviedo, Asturias, Spain; *Corresponding author, E-mail: carde-
\end{abstract} nesvictor@uniovi.es

(Received: October 31, 2019; Revised accepted: July 15, 2020)

https://doi.org/10.18814/epiiugs/2020/0200s07

Roofing slate from the town of Bernardos can be found in most buildings erected by the Spanish monarchy from the $16^{\text {th }}$ to $19^{\text {th }}$ centuries, making it a highly important component of Spain's architectural heritage. The quarries are located outside Bernardos, $145 \mathrm{~km}$ north of Madrid, in the Precambrian terrains of the Iberian Variscan Orogen. Although from a petrographic point of view this rock is in fact a phyllite, for the purposes of construction it is known as roofing slate. Bernardos phyllite has a set of specific characteristics that make it a unique rock which is clearly distinct from other roofing slates. These particular features, together with the history and singularity of the outcrops, make it an ideal candidate for Global Heritage Stone Resource (GSHR) status. Today there is no longer any convenient replacement for this stone, which makes it very important to give it the best possible recognition in order to ensure the availability of this resource in the future. This paper reviews the historical meaning and petrophysical characteristics of this rock, and proposes it be designated as a GSHR.

\section{Introduction}

Slate has been used in the Iberian Peninsula since the end of the Neolithic-Chalcolithic age (4,500 BC). The first records correspond to tumuli (ancient grave mounds) in Galicia and Extremadura (Ponce de Leon, 2012), areas which have significant slate outcrops. Its first use in civil architecture as a covering material (i.e., roofing slate) is documented in the thermal baths of Espasante, Galicia, built during the $1^{\text {st }}$ to $2^{\text {nd }}$ century $\mathrm{AD}$. This early use of roofing slate, however, was restricted to areas neighboring on the outcrops, which were mined by locals with the same tools that they used for agriculture, such that production was very limited.

The first true roofing slate quarry in Spain was opened in Bernardos in 1559 by appointment of King Philip II, and so Bernardos played an essential role in the royal architectural styles from that time up through the $19^{\text {th }}$ century. Some of the most important Spanish heritage buildings are covered with this type of roofing slate, the most representative structure being the Monastery of San Lorenzo de El Escorial.

\section{Historical Context}

"And so I ordered that eight apt skilled workers should be sought, two to extract the slate, four to cut, polish, and lay the pieces, and the last two to build the wooden frames for the roofs and assemble them." These words (Bernardos-Sánz and López-Mesones, 2017; Iglesias Ponce de León, 1995) were written by King Philip II of Spain, Portugal and Naples in 1559. Philip II, son of the Holy Roman Emperor Charles V, brought the Spanish Empire into its so-called "Golden Age." As a young prince, Philip had visited several European countries, and was fascinated by the European style of slate roofing, especially by how it shone as it reflected the sunlight (Ceballos-Escalera and CeballosEscalera, 2010). Shortly after he was crowned King Philip II, he ordered new royal buildings to be erected with slate roofs on them, and advised against the use of lead on roofs due to weathering issues. To this end, he had prospectors seek out slate in the vicinity of Madrid, and after several surveys they located the best outcrops in the town of Bernardos, in the province of Segovia (Fig. 1). Since there was little or no tradition of building with slate, slate masters were brought in from Flanders (Belgium) and Angers (France), along with their tools and even nails with which to attach the slate (Cano, 1991).

As the quarries were the property of the Crown, their output was used exclusively in royal buildings, although some slate was occasionally smuggled out for local use. The work in the quarry was divided up according to the classic division of labor into two categories: extractors or miners, and manufacturers. This division is common in many other countries and at different times. Arguments and fights between these two groups were common, as the manufacturers often complained about the quality of the stone provided by the miners. The emergence of the slate industry boosted the local economy. The work was hard, usually from dawn till dusk, and the salaries were high by the standards of the time, especially for the foreign experts. Slate shingles were manufactured following a more or less standard dimension, known as the Royal Measure $(42 \times 15-18 \mathrm{~cm})$, with a thickness of $5 \mathrm{~mm}$. Each shingle weighted about $1 \mathrm{~kg}$. Slate shingles were packed using ropes, and then loaded onto mules or carts. Mules carried less weight, but were preferred over carts, since the clattering of the load during transportation caused more pieces to break than in the case of mules. If more than $3 \%$ of the pieces were broken on arrival the shipper would be fined, 


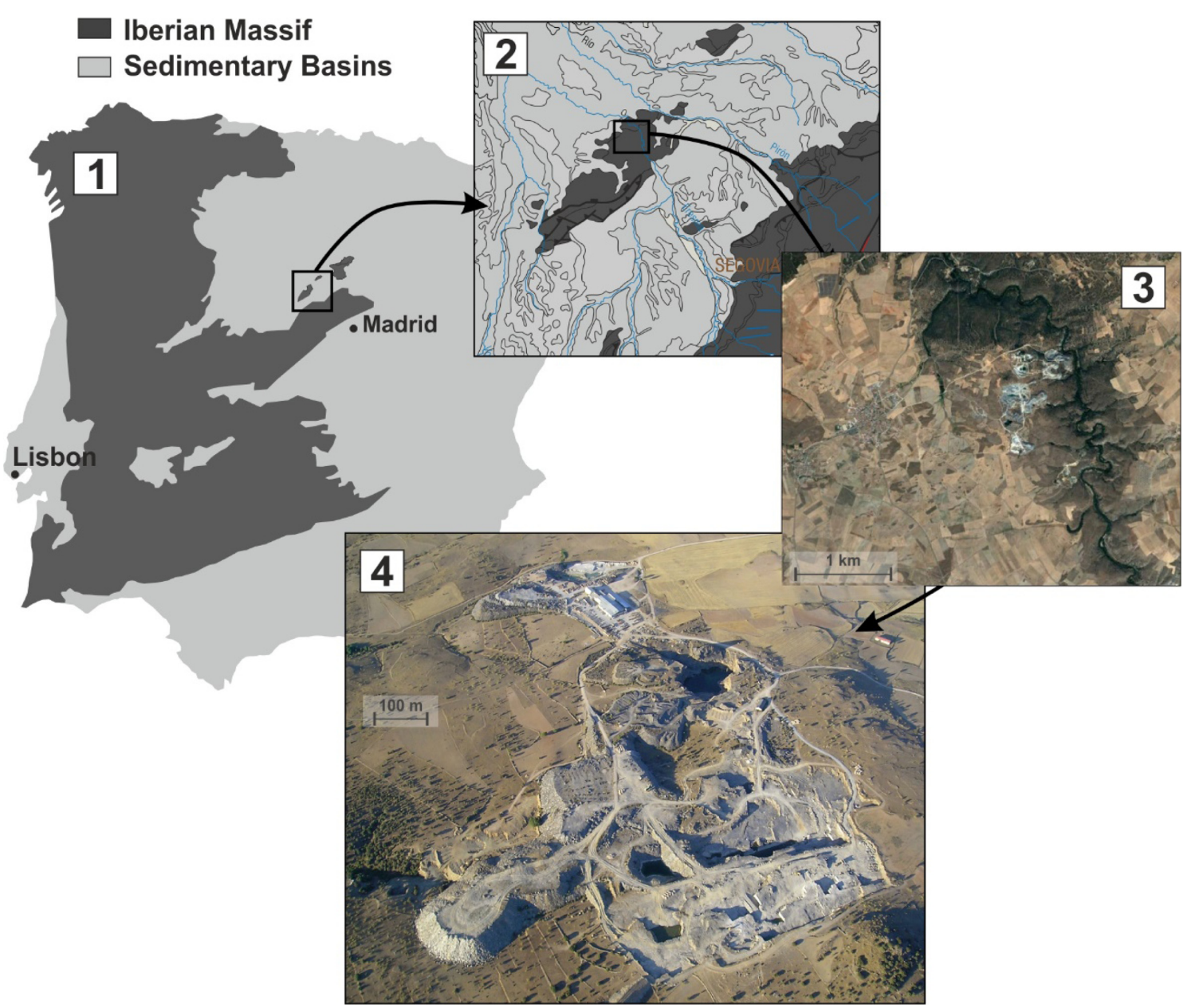

Figure 1. (1) Geological and geographical context of the Bernardos quarries, (2) Spanish Geological Survey (IGME), (3) Google Earth, (4) Aerial photo, courtesy of Naturpiedra S.L.

but since mules were most widely used the percentage of broken pieces tended to be well below this figure. In the beginning, the price of the slate was calculated taking into account the sum of the salaries of all the workers involved in the production and transportation process. Afterwards, the king set a standard price for each shingle at eight and a half maravedís (Bernardos-Sánz and López-Mesones, 2017). This price was maintained for more than a century and a half, but by 1711 the excess of supply caused the price to drop almost $50 \%$. In any case, roofing slate was an expensive material, more than 8 times the price paid for a ceramic roof tile. This fact reflects the hierarchy of construction stones, in which roofing slate was considered to be the best material available. Installing a complete roof with slate was a very expensive endeavor, reserved only for royal buildings, churches or the palaces of the nobility, and in many cases the slate was only installed on the most salient parts, such as towers and spires.

The first three royal buildings with slate roofs were the Palace of Valsaín in the forest of Segovia, the palace of El Pardo, and the Royal Alcázar of Madrid, although the most symbolic building is the Monastery of San Lorenzo de El Escorial, erected between 1563 and 1584. The design of this building was strongly influenced by the king's own ideas. The Italian Renaissance style was revised and adapted, excluding all elements considered embellished or ornamental. The result is a building of compact and austere grandeur, with a Flemish-style slate roof that ushered in a whole new architectural mode in Spain, the Habsburg style (Estilo Austria). The monastery has suffered several fires throughout its history, the most devastating one occurring in 1671. Over 400,000 new slate shingles were required to repair the roof, which gives an idea of the building's dimensions. King Philip II's enthusiasm for architecture left behind an important legacy of royal buildings, which were subsequently maintained by his successors. The use of roofing slate was established and maintained as a distinctive style for the Spanish monarchy until the $19^{\text {th }}$ century, when the decline of Spain's economic strength and the indifference of the new Bourbon monarchs led to the abandonment of many longstanding royal buildings (Lindoso Tato, 2015). In many cases, the slate roof was substituted with a cheaper material, and in others the building was simply abandoned.

In 1909, an English company, The Bernardos Slate Quarries, Ltd., opened a new quarry in Bernardos after a long search for roofing slate outcrops all over the Iberian Peninsula. English mining companies revitalized the slate industry in Spain and Portugal, and opened new quarries at other sites as well, such as Valongo, in Portugal, and Valdeorras (Cárdenes et al., 2019a), in Spain. In Bernardos, English management lasted until 1928, when the company ceased operations. However, the remaining quarries and mills were purchased by Spanish businessmen, keeping the industry alive. In 1936, the Spanish Civil War swept the country, and after the war's end in 1939, Spain had to face very difficult 
times due to the isolation of Franco regime following the Allies' victory in World War II. This isolation deeply affected the Spanish economy until the 1960s, when an incipient economic recovery was led by the emerging tourism industry. This decade also saw the birth of the Spanish roofing slate industry in Galicia (NW Spain), which in just a few years came to dominate the world's roofing slate production. The Bernardos slate manufacturers also took advantage of this new situation, and the historic quarries were reborn once more. Today, Bernardos roofing slate is produced and exported all over the world, and enjoys a sound reputation in terms of durability and performance.

\section{Criteria for Global Heritage Stone Resource Designation}

The representativeness of Bernardos phyllite in Spanish architectural heritage cannot be overstated, as it is one of the characteristic elements that define Spanish royal architecture from the $16^{\text {th }}$ to $19^{\text {th }}$ centuries. The GHSR designation was established to recognize the value of unique rocks that are a necessary part of historic and heritage buildings and monuments. The designation is also intended to encourage suitable management of the GHSR, assuring its availability for future generations (Cooper, 2015). The criteria for granting this designation include the following; 1) the stone must have been used for a significant period of time; 2) the stone must have been used over a wide geographical area; 3 ) the stone must have been used in exceptional works; and 4) the stone can be recognized as a local or national symbol. Bernardos phyllite fulfills all of these requirements, being one of the most characteristic dimension stones in Spain.

\section{Required GHSR Information}

\section{Formal name}

Filita de Bernardos / Bernardos phyllite

Commercial designation

Pizarras del Castillo, Pizarra de Bernardos, Filita de Bernardos, Filita Gris Cordillera.

\section{Place of origin}

Bernardos (Segovia), Spain.

\section{Resource location}

The resources are located to the east of the municipalities of Bernardos and Carbonero el Mayor, and are the only quarries available for this rock.

\section{Quarries}

The quarries are located on the outskirts of Bernardos, Segovia, about $145 \mathrm{~km}$ northwest of Madrid, along the river Eresma. The river has exposed the slate deposits, and also provides water for the quarry operations. Nowadays, the quarries are worked by the company Naturpiedra (www.naturpiedra.com), which maintains exclusive control over this stone. The working quarries are:

- Engorduro, with a surface area of 74 ha and estimated resources of 2,000,000 tons.

- El Castillo, with a surface area of 6 ha and estimated resources of 250,000 tons.

- Los Ingleses and Valserrano, which are currently closed.

\section{Heritage Issues}

Geological investigations have revealed large reserves of resources, meaning the availability is assured. That said, the use of foreign materials similar to Bernardos phyllite has been recognized in recent years in restoration works. While these foreign roofing slates may look similar, their petrography, mineralogy and especially weathering behavior are very different, and in some extreme cases could place the integrity of an entire roof at risk. It is therefore very important to make a clear distinction between this Bernardos phyllite and other stones which look similar but are in fact of inferior quality.

\section{Petrographic Description and Mineralogy}

Bernardos phyllite is a phyllite used as roofing slate. It is a blackgrey phyllite, coded as B2 according to the International Roofing Slate Classification (Cárdenes et al., 2019b). "Roofing slate" is a construction term, and refers to a metamorphic rock that can be split into thin, regular shingles suitable for roofing. While most roofing slates are true slates, other lithologies are used as well, such as low-grade slates, phyllites and mica-schists (Cárdenes et al., 2014).

A petrographic examination using transmitted-light optical microscopy reveals a fine-grained metamorphic rock (Fig. 2), in which it is possible to observe relict sedimentary planes $\left(\mathrm{S}_{0}\right)$ and a well-developed slaty cleavage $\left(\mathrm{S}_{1}\right)$, which allows the rock to be split into the shingles. The mineralogical composition is quartz, mica and chlorite, as is normally the case in roofing slates. The occurrence of biotite as one of the mica minerals indicates that the rock has crossed the biotite isograde, which is why it is classified as phyllite (Schmid et al., 2007). X-ray diffraction semi-quantitative analysis has detected the following mineral proportions: quartz $33.8 \%$; muscovite $25.2 \%$; biotite $13.6 \%$; chamosite $21.4 \%$; and feldspar $6.0 \%$. Other minerals can be found in minor proportions, such as carbonates and iron sulfides. The main elements, as defined by X-ray fluorescence, are also within the normal range for a roofing slate (Table 1).

\section{Color}

The color of this rock has been described as grey-greenish, and sometimes bluish in hand specimens. However, this color perception is determined by the observer and the lighting at the time of observation. The CIELAB color coordinates and brightness for this rock are $\mathrm{L}^{*}=42.2, \mathrm{a}^{*}=-0.3, \mathrm{~b}^{*}=0.3, \mathrm{C}_{\mathrm{ab}}^{*}=0.5, \mathrm{~h}_{\mathrm{ab}}=137$, and brightness $=16.5$. In this sense, compared with other roofing slates from the Iberian Peninsula, Bernardos slate is clearly different (Fig. 3).

\section{Natural Variability}

Color and texture are rather homogeneous for all outcrops of Bernardos phyllite. There are, however, some variations in carbonate content. These carbonates are secondary minerals, and were deposited through the action of meteoric water. Joints and fractures on the quarry front usually display multicolor patinas due to weathering. In some parts of the quarries there is also variation due to the occurrence of sandy levels and quartzites. These quartzites are currently exploited for walls, paving and other masonry works. 

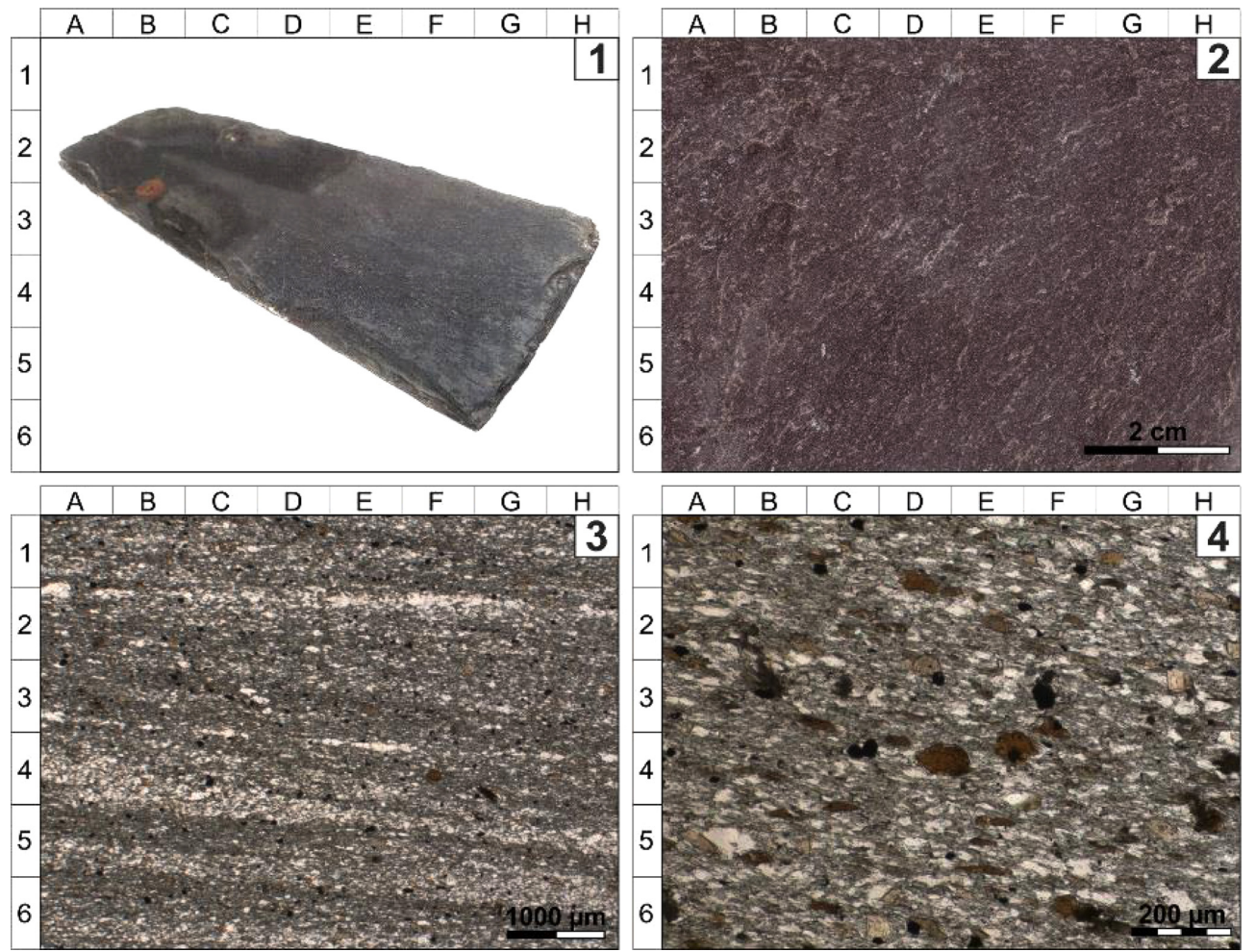

Figure 2. Macro- and microphotographs of the Bernardos phyllite. [1] Recovered shingle from the El Escorial Monastery. This shingle is approximately 300 years old, and its dimensions follow the Royal Measure of $40 \times 15 \mathrm{~cm}$ (Bernardos-Sánz and López-Mesones, 2017), [2] Appearance of Bernardos phyllite in a hand specimen. [3 and 4] Transmitted-light microphotographs. The slaty cleavage can be observed from left to right in 3. The white minerals correspond to chlorites (chamosite), quartz and feldspar, while the brown minerals are biotite and the opaque minerals are iron sulfides.

Table 1. Main elements of Bernardos phyllite (as a percentage)

\begin{tabular}{cccccccccccc}
\hline \hline $\mathrm{SiO}_{2}$ & $\mathrm{Al}_{2} \mathrm{O}_{3}$ & $\mathrm{Fe}_{2} \mathrm{O}_{3}$ (tot) & $\mathrm{MnO}$ & $\mathrm{MgO}$ & $\mathrm{CaO}$ & $\mathrm{Na}_{2} \mathrm{O}$ & $\mathrm{K}_{2} \mathrm{O}$ & $\mathrm{TiO}_{2}$ & $\mathrm{P}_{2} \mathrm{O}_{5}$ & $\mathrm{CO}_{2}$ & $\mathrm{SO}_{4}$ \\
\hline 52.84 & 23.50 & 8.83 & 0.10 & 2.95 & 0.29 & 1.04 & 4.31 & 1.33 & 0.16 & 0.46 & 0.00 \\
\hline
\end{tabular}

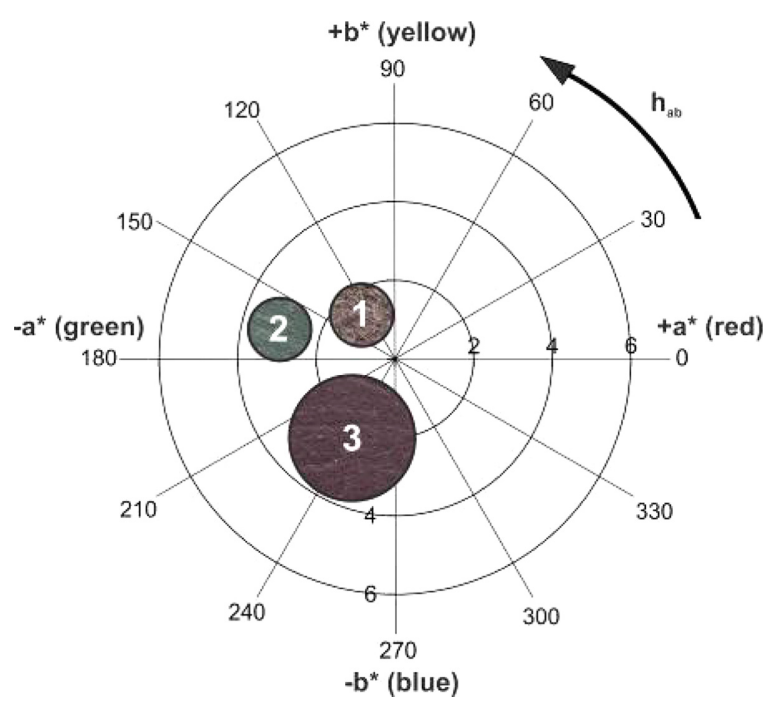

Figure 3. Color diagram for Spanish roofing slates. Group 1 corresponds to Bernardos phyllite, Group 2 to green phyllites from Lugo, and Group 3 to roofing slates from Galicia. The size of the circles represents the dispersion of the measurements. Most of Spanish roofing slates (up to 98\%) correspond to Group 1. From a practical standpoint, Bernardos grey phyllites are lighter than those from Group 1, and have a more crystalline texture. Modified from Cárdenes et al. (2012).

\section{Suitability}

This stone has the optimal textural, physical and chemical characteristics for use in roofing, as proven by the many centuries of old roofs found throughout the region. Also, the exceptionality of the outcrops (lack of important tectonic deformation and/or joints) has preserved the rocky massif intact. There is no doubt that this stone fulfills the requirements (Cárdenes et al., 2014) for use as a roofing slate.

\section{Geological Setting and Stratigraphy}

The geology corresponds to the Massif of Santa María La Real, (Iberian Massif), an outcrop of Precambrian - Lower Cambrian materials, affected by the Hercynian Orogeny and surrounded by the Tertiary basin of eastern Spain. These materials correspond to the Schist-Greywacke Complex (Carrington da Costa, 1950), a series of pelitic and carbonate sediments of different grain sizes affected by metamorphism. Productive roofing slate levels are located in the upper zone of the Complex. Intercalated between these productive levels are sandy levels and some carbonate levels. 
Table 2. Technical values for Bernardos phyllite, compared with averaged values for slates strictu sensu and phyllites. The number of slates s.s. is much higher than that of phyllites, due to the fact that phyllite outcrops used as roofing slates are scarce. For bending strength, L is for longitudinal and $T$ is for transversal. It is worth pointing out that the lower values detected for weatherable minerals in Bernardos phyllite offer insight into the rock's high durability. Code T1 refers to (low) oxidation potential (T1-T2-T3) according to EN 12326, while code S1 refer to (low) reaction to sulfurous environment, also according to EN 12326. Please refer to EN 12326 for more information on test methods. The data are from technical sheets provided by the quarrying companies

\begin{tabular}{|c|c|c|c|}
\hline Test method & Bernardos phyllite & Mean for slates s.s. $(n=143)$ & Mean for phyllites $(\mathrm{n}=7)$ \\
\hline Bending strength (MPa) & L: 52.0 / T: 35.0 & L: 64.2 / T: 56.1 & $\mathrm{~L}: 52.7 / \mathrm{T}: 41.5$ \\
\hline Water Absorption & $0.26 \%$ & $0.28 \%$ & $0.22 \%$ \\
\hline $\mathrm{C}$ content & $0.08 \%$ & $0.49 \%$ & $0.30 \%$ \\
\hline $\mathrm{CaCO}_{3}$ content & $0.13 \%$ & $1.46 \%$ & $0.95 \%$ \\
\hline Thermal cycle & $\mathrm{T} 1$ & $\mathrm{~T} 1$ & $\mathrm{~T} 1$ \\
\hline
\end{tabular}

\section{Physical/chemical Properties}

According to tests performed following EN 12326, the European Norm that standardizes the requirements for roofing slates, Bernardos phyllite presents normal values for physical and chemical properties compared to values from other roofing slates and phyllites averaged from technical sheets and data provided by companies (Table 2).

\section{Vulnerability and Maintenance of Supply}

As pointed out before, the occurrence of Bernardos phyllite is restricted to Bernardos, and there is only one company currently working these quarries. This makes its production especially vulnerable, since if the company were to fail, the supply of this stone would end immediately.

Table 3. Selection of historic buildings with Bernardos phyllite. A more detailed inventory can be seen in (Bernardos-Sánz and López-Mesones, 2017), and also at www.naturpiedra.com

\begin{tabular}{|c|c|c|c|c|}
\hline Year & Place & Denomination & Element & Pieces \\
\hline 1603 & Uclés & Monastery & spires & 26,000 \\
\hline 1646 & Salamanca & Recoletos School & cover & 26,000 \\
\hline $1669-1672$ & Madrid & Royal Armory & cover, repair & 26,000 \\
\hline 1703 & Madrid & Comendadoras de Santiago Church & spires & 24,000 \\
\hline 1716 & Madrid & Royal wash places & & 30,000 \\
\hline 1717 & Madrid & Royal Palace & & 30,000 \\
\hline 1725 & Rascafría & Monastery of El Paular & chapel & 26,868 \\
\hline 1729 & La Aguilera & Convent of Domus Dei & chapel & 25,000 \\
\hline 1736 & El Escorial & Monastery of El Escorial & & 60,000 \\
\hline 1738 & El Escorial & Monastery of El Escorial & roof of the seminary & 60,000 \\
\hline 1738 & El Pardo & Palace & roof & 30,000 \\
\hline 1741 & El Pardo & Palace & four spires & 40,000 \\
\hline
\end{tabular}

Table 4. Selected modern buildings with Bernardos phyllite, and the architecture prizes obtained by some of them

\begin{tabular}{cccc}
\hline \hline Year & Place & Denomination & Prizes \\
\hline 2017 & Jäder, Sweden & Church & \\
2017 & Madrid, Spain & Mutua Madrileña & \\
2015 & Haute Savoie, France & Abbaye d'Abondance \\
2011 & Madrid, Spain & Telefonica City of Telecommunications & \\
2011 & La Rioja, Spain & Winery La Grajera & MosBuild Architecture and Design Awards, 2012 \\
2006 & Barcelona, Spain & Media Complex TV headquarters & Premi Ciutat de Barcelona, 2006 \\
& & & $10^{\text {th }}$ Spanish Architecture Biennale, 2009 \\
2004 & Madrid, Spain & Chamber of Commerce & \\
2003 & Alzuza, Spain & Jorge Oteiza Museum & \\
1999 & San Sebastian, Spain & Kursaal Museum & Mies van der Rohe, 2001 \\
1995 & Las Rozas, Spain & Bank of Madrid offices & College of Architects, 1995 \\
& & & Iberfad of Architecture, 1997 \\
& & & Spanish Architecture Biennale, 1997 \\
\hline
\end{tabular}




\section{Historic Use and Geographic Area of Utilization}

Since the $16^{\text {th }}$ century this stone has been used in the central area of Spain, mainly around Madrid and Segovia. In recent years, the company Naturpiedra has expanded the market, and today Bernardos phyllite is sold all over the world, especially in Europe and the USA.

\section{Selected Buildings}

As pointed before, this rock is widely used in Spanish architectural heritage buildings (Table 3 ), but is also present in contemporary architecture (Table 4, Fig. 4). The use of slabs for walls and paving is also very popular in modern buildings.
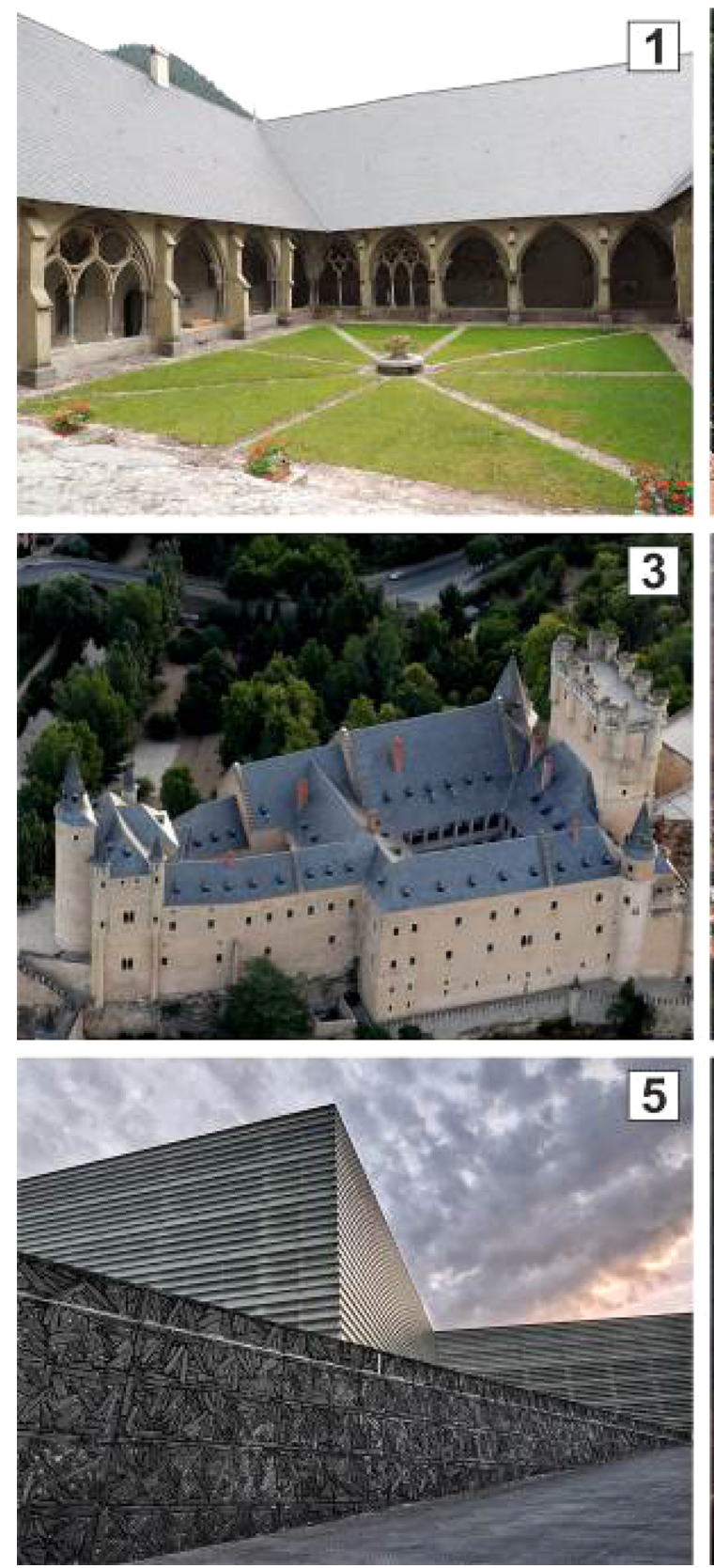

\section{Conclusions}

Bernardos phyllite is one of Spain's flagship dimension stones. Its long history and representativeness in some of the most important Spanish heritage buildings and monuments, together with other features, such as uniqueness and wide-ranging use, as detailed by Cooper (2015), make it an ideal candidate for the Global Heritage Stone Resource designation.

Today this rock is being quarried and exported to many countries around the world, and has become a point of reference for architects. However, it is important to raise awareness about its availability and status, since the continued well-being of many heritage buildings directly depends on it.
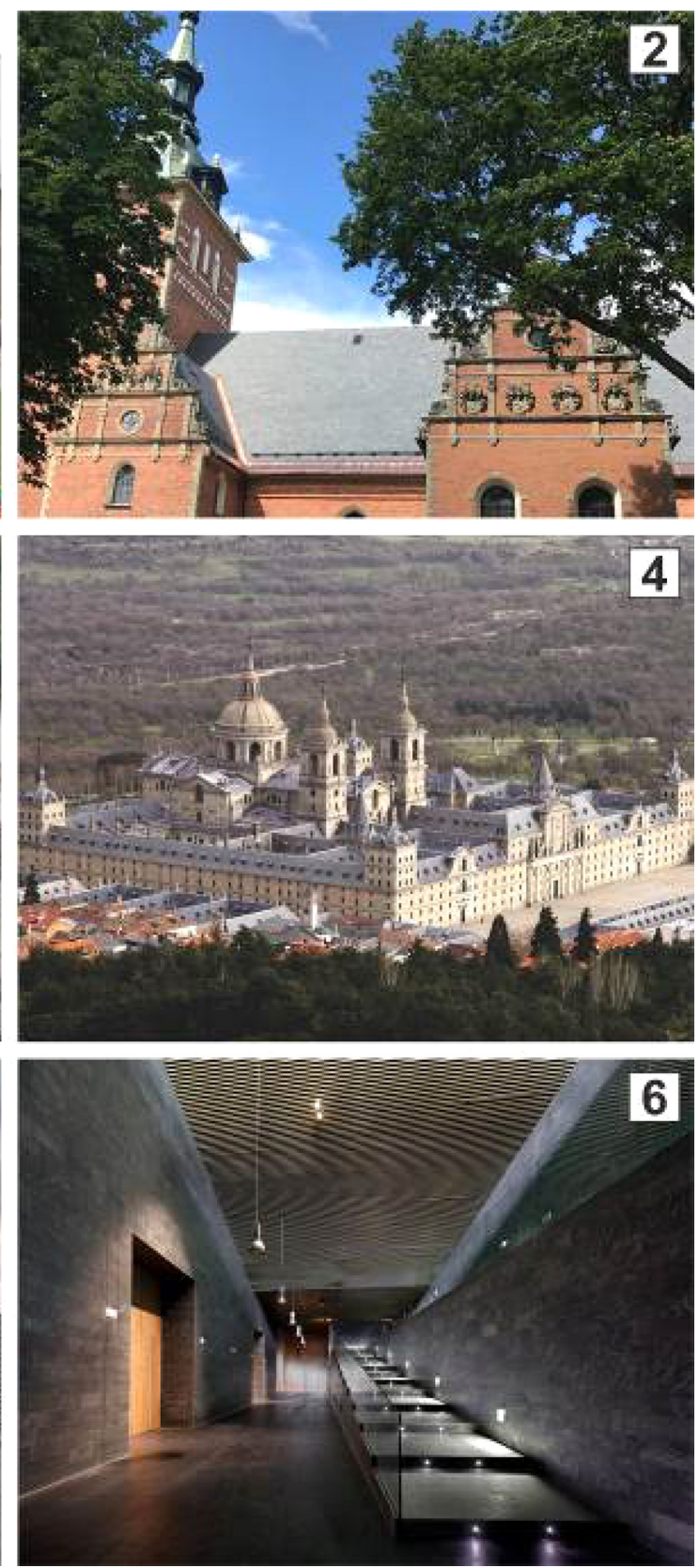

Figure 4. (1) Abbaye d'Abondance, France, (2) Jäders Kirkra, Sweden, (3) Alcazar of Segovia, Spain, (4) Monastery of El Escorial, Spain, (5) Kursaal, Spain, (6). 


\section{Acknowledgements}

Víctor Cárdenes holds a Clarín PA-18-ACB17-11 grant from the Government of Asturias (Spain). Authors are also grateful to roofing slate consultant Jeffrey S. Levine for his accurate comments.

\section{References}

Bernardos-Sánz, J.U., and López-Mesones, F., 2017, Historical and architectural value of the slates of Bernardos. Naturpiedra.

Cano, J.L., 1991, Las cubiertas de pizarra en las obras reales de Felipe II y su tránsito al siglo XVII: Antecedentes de la Arquitectura Barroca Española. Boletin del Seminario de Estudios de Arte y Arqueologia, v. 57, pp. 291-300.

Cárdenes, V., Prieto, B., Sanmartín, P., Ferrer, P., Rubio, A., and Monterroso, C., 2012, Influence of Chemical-Mineralogical Composition on the Color and Brightness of Iberian Roofing Slates. Journal of Materials in Civil Engineering, v. 24, pp. 460-467.

Cárdenes, V., Rubio-Ordóñez, Á., Wichert, J., Cnudde, J.P., and Cnudde, V., 2014, Petrography of roofing slates. Earth-Science Reviews, v. 138, pp. 435-453.

Cárdenes, V., Ponce de León, M., Rodríguez, X.A., and Rubio-Ordoñez, A., 2019a, Roofing Slate Industry in Spain: History, Geology, and Geoheritage. Geoheritage, v. 11, pp. 19-34.

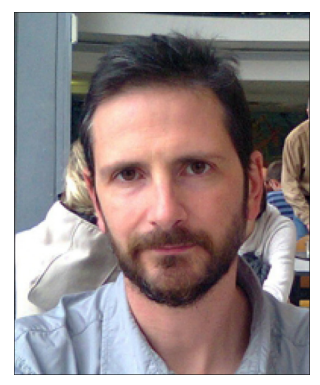

Víctor Cárdenes holds a $\mathrm{PhD}$ in Geology. He has published more than 30 papers and studies on roofing slates. Currently he is working at the Oviedo University, Spain, in the framework of a Clarín project granted by the Spanish Ministry of Science and the local government of Asturias.

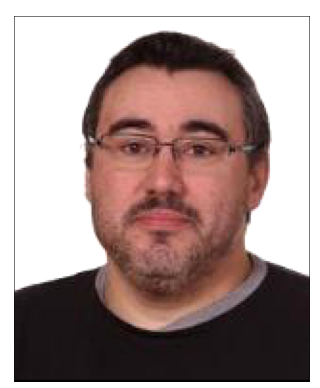

Álvaro Rubio is Professor in the Department of Geology of Oviedo University, Spain. He has been teaching Petrology and Geochemistry for the past 15 years.
Cárdenes, V., Rubio-Ordoñez, A., and Ruiz de Argandoña, V.G., 2019b (Accepted), Definition of Roofing Slate Lithotypes and their Physical and Petrographical Characteristics. Key Materials in Engineering.

Carrington da Costa, J., 1950, Noticia sobre uma carta geologica do Buçaco, de Nery Delgado, Lisboa.

Ceballos-Escalera, A., and Ceballos-Escalera, L., 2010, Influencias del arte flamenco en España: El empizarrado. Las reales minas de pizarra de Bernardos y de Carbonero el Mayor, en tierras de Segovia. Anales del Cincuentenario, v. 1, pp. 57-83.

Cooper, B.J., 2015, The 'Global Heritage Stone Resource' designation: past, present and future. In: Pereira, D., Marker, B.R., Kramar, S., Cooper, B.J. $\&$ Schouenborg, B.E. (Editors) Global Heritage Stone: Towards International Recognition of Building and Ornamental Stones. Geological Society of London Special Publication v. 407, pp. 11-20.

Iglesias Ponce de León, M., 1995, L'ardoise en Espagne: Histoire et economie, Universite de Rennes 2, Rennes.

Lindoso Tato, E., 2015, La industria de la pizarra española en perspectiva histórica. Investigaciones de Historia Económica - Economic History Research, v. 11, pp. 52-61.

Ponce de Leon, M., 2012, L'ardoise en Espagne. De la Prehistoire aux Hispano-Romains. In: G. Marchand and G. Querre (Editors), Roches et sociétés de la Préhistoire. Presses universitaires de Rennes, 351-375 p.

Schmid, R., Fettes, D., Harte, B., Davis, E., and Desmons, J., 2007, How to name a metamorphic rock. In: D. Fettes and J. Desmons (Editors), Metamorphic Rocks. A Classification and Glossary terms. Cambridge University Press.

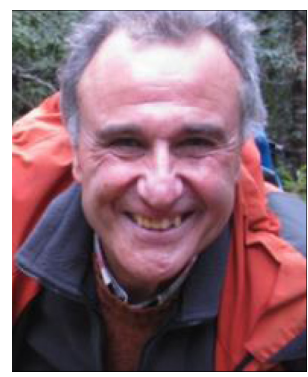

Vicente Gómez Ruiz de Argandoña is also Professor at the Department of Geology of Oviedo University specializing in Sedimentary Petrology, Soil Mechanics, and Petrophysics. He has also worked on $\mathrm{CO}_{2}$ sequestration and conservation of monumental heritage. 